\title{
Vertical distribution of bacteria and intensity of microbiological processes in two stratified gypsum Karst Lakes in Lithuania
}

\author{
A. Krevs ${ }^{(1)}$, A. Kucinskiene ${ }^{(1,2)}$ \\ Received November 22, 2010 \\ Revised December 13, 2010 \\ Accepted February 10, 2011
}

Key-words: bacteria, microbial processes, karst lakes

\section{ABSTRACT}

Physical-chemical parameters and the vertical distribution of bacteria and organic matter production-destruction processes were studied during midsummer stratification in two karst lakes (Kirkilai and Ramunelis) located in northern Lithuania. The lakes were characterized by high sulfate concentrations $\left(369-1248 \mathrm{mg} \cdot \mathrm{L}^{-1}\right)$. The $\mathrm{O}_{2} / \mathrm{H}_{2} \mathrm{~S}$ intersection zone formed at 2-3 $\mathrm{m}$ depth. In Lake Kirkilai, the highest bacterial densities (up to $8.7 \times 10^{6} \mathrm{cell} \cdot \mathrm{mL}^{-1}$ ) occurred at the $\mathrm{O}_{2} / \mathrm{H}_{2} \mathrm{~S}$ intersection zone, whereas in Lake Ramunelis the highest densities were observed in the anoxic hypolimnion (up to $11 \times 10^{6} \mathrm{cell} \cdot \mathrm{mL}^{-1}$ ). Pigment analysis revealed that green sulfur bacteria dominated in the microaerobic-anaerobic water layers in both lakes. The most intensive development of sulfate-reducing bacteria was observed in the anaerobic layer. Photosynthetic production of organic matter was highest in the upper layer. Rates of sulfate reduction reached $0.23 \mathrm{mg} \mathrm{S}^{2-} \cdot \mathrm{dm}^{3} \cdot \mathrm{d}^{-1}$ in the microaerobic-anaerobic water layer and $1.97 \mathrm{mg} \mathrm{S}^{2-} \cdot \mathrm{dm}^{3} \cdot \mathrm{d}^{-1}$ in sediments. Karst lakes are very sensitive to organic pollution, because under such impact in the presence of high sulfate amounts, sulfate reduction may become very intensive and, consequently, the increase in hydrogen sulfide and development of sulfur cycle bacteria may reduce the variety of other hydrobionts.

RÉSUMÉ

Distribution verticale des bactéries et processus microbiologiques dans deux lacs stratifiés d'un karst gypseux en Lituanie

Mots-clés : bactérie, processus microbiologique, lac karstique
Les paramètres physico-chimiques, la distribution verticale des bactéries et les processus de production-décomposition de la matière organique ont été étudiés pendant la stratification estivale dans les lacs de karst Kirkilai et Ramunelis au nord de la Lituanie. Les lacs sont caractérisés par de fortes concentrations en sulfates (369-1248 mg. $\left.\mathrm{L}^{-1}\right)$. L'interface $\mathrm{O}_{2} / \mathrm{H}_{2} \mathrm{~S}$ se forme vers $2-3 \mathrm{~m}$ de profondeur. Dans le lac Kirkilai, la plus grande densité de bactéries (jusqu'à $8,7 \times 10^{6}$ cellules $\cdot \mathrm{mL}^{-1}$ ) se trouve à l'interface $\mathrm{O}_{2} / \mathrm{H}_{2} \mathrm{~S}$ alors que dans le lac Ramunelis elle est dans I'hypolimnion anoxique (jusqu'à $11 \times 10^{6}$ cellules $\cdot \mathrm{mL}^{-1}$ ). D'après l'analyse pigmentaire, les bactéries photosynthétiques du soufre dominent dans les couches anoxiques des deux lacs. Le développement le plus important de bactéries $O$ réductrices des sulfates est relevé dans les couches anoxiques. De la production photosynthétique de matière organique existe dans toute la colonne d'eau avec un maximum dans la couche supérieure. La réduction des sulfates a été estimée dans les couches

(1) Institute of Botany of Nature Research Centre, Zaliuju ezeru 49, Vilnius 08406, Lithuania, 


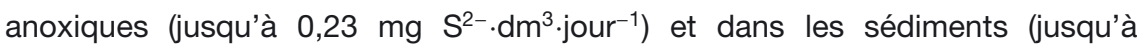
$\left.1,97 \mathrm{mg} \mathrm{S}^{2-} \cdot \mathrm{dm}^{3} \cdot \mathrm{jour}^{-1}\right)$. Ces lacs karstiques sont très sensibles à la pollution organique, parce que, dans ce cas, en présence de fortes concentrations en sulfates, la réduction des sulfates peut devenir très intense et, en conséquence, l'augmentation du sulfure d'hydrogène et le développement des bactéries du cycle du soufre peuvent réduire la biodiversité.

\section{INTRODUCTION}

Karst lakes are typically small, but relatively deep, and their chemistry is strongly influenced by minerals and ions found in the groundwater (Miracle et al., 1992; Alimova and Mingazova, 2001). These specific features of karst lakes influence the functioning of their ecosystems. Karst lakes exhibit stable stratification, which is conducive to sharp vertical stratification of different groups of microorganisms (Vicente and Miracle, 1988; Garcia-Gil et al., 1996; Camacho et al., 2003). Therefore, these lakes are interesting model systems for the investigation of the different groups of microorganisms which succeed each other along the vertical gradient. Despite these similarities, plankton structure and production are known to differ among karst lakes of similar genesis and morphometric parameters even within one catchment area (Alimova and Mingazova, 2001; Palagushkina, 2004; Gusev, 2008).

In the karst region of northern Lithuania, the leaching of gypsum in Devonian rocks results in the formation of sinkholes in which arise small (0.01-4.0 ha), but relatively deep (5-10 m) waterbodies possessing connections with underground waters (Kilkus and Taminskas, 2000). Elevated mineralization (dissolved salts up to $2.0 \mathrm{~g} \cdot \mathrm{L}^{-1}$ ) and the dominance of sulfates (the concentration of $\mathrm{Ca}^{2+}$ and $\mathrm{SO}_{4}^{2-}$ reaches up to 0.6 and $1.4 \mathrm{~g} \cdot \mathrm{L}^{-1}$, respectively) are distinguishing features of these kinds of lakes (Taminskas and Marcinkevicius, 2002). The gypsum karst lakes of sulfate water type in Lithuania are included in the list of European Union important habitats (code 3190) due to their unique and rare characteristics (Rasomavicius, 2001). High sulfate concentrations in water and bottom sediments provide favorable conditions for the development of sulfate-reducing bacteria (Paskauskas et al., 2005). Massive development of sulfur-oxidizing bacteria occurs at the chemocline of sulfide-rich lakes (Gorlenko et al., 1977; Camacho et al., 2000; Overmann and Garcia-Pichel, 2006). Such development of purple sulfur bacteria (Chromatium okeanii) has also been reported during summer stratification in the karst lake Kirkilai in Lithuania (Zvikas, 2004). The variety of microorganisms and especially of bacteria involved in the sulfur cycle of karst lakes in Lithuania has not been sufficiently investigated. At present, there is little information about the intensity and character of microbiological processes in these lakes (Zvikas, 2004; Paskauskas et al., 2005).

The objectives of this study were to investigate midsummer vertical distributions of bacteria and the intensity of organic matter production - destruction processes in two karst lakes in the context of their physical and chemical characteristics.

\section{STUDY AREA AND METHODS}

\section{$>$ STUDY AREA}

The two investigated lakes (Kirkilai and Ramunelis) are situated in an active karst region in the northern part of Lithuania (Figure 1). Kirkilai is the largest lake of this basin with a surface area of $4 \mathrm{ha}$, maximum depth of $6.3 \mathrm{~m}$ and mean depth of $1.07 \mathrm{~m}$. The lake formed following the connection of $\sim 30$ sinkholes which differed in age and size. Lake Ramunelis is located to the east of Lake Kirkilai and occupies less than 0.1 ha in area with a maximum depth of $5.0 \mathrm{~m}$. The banks of the lakes are overgrown with bushes and trees. During the spring flood, both lakes often interflow. 


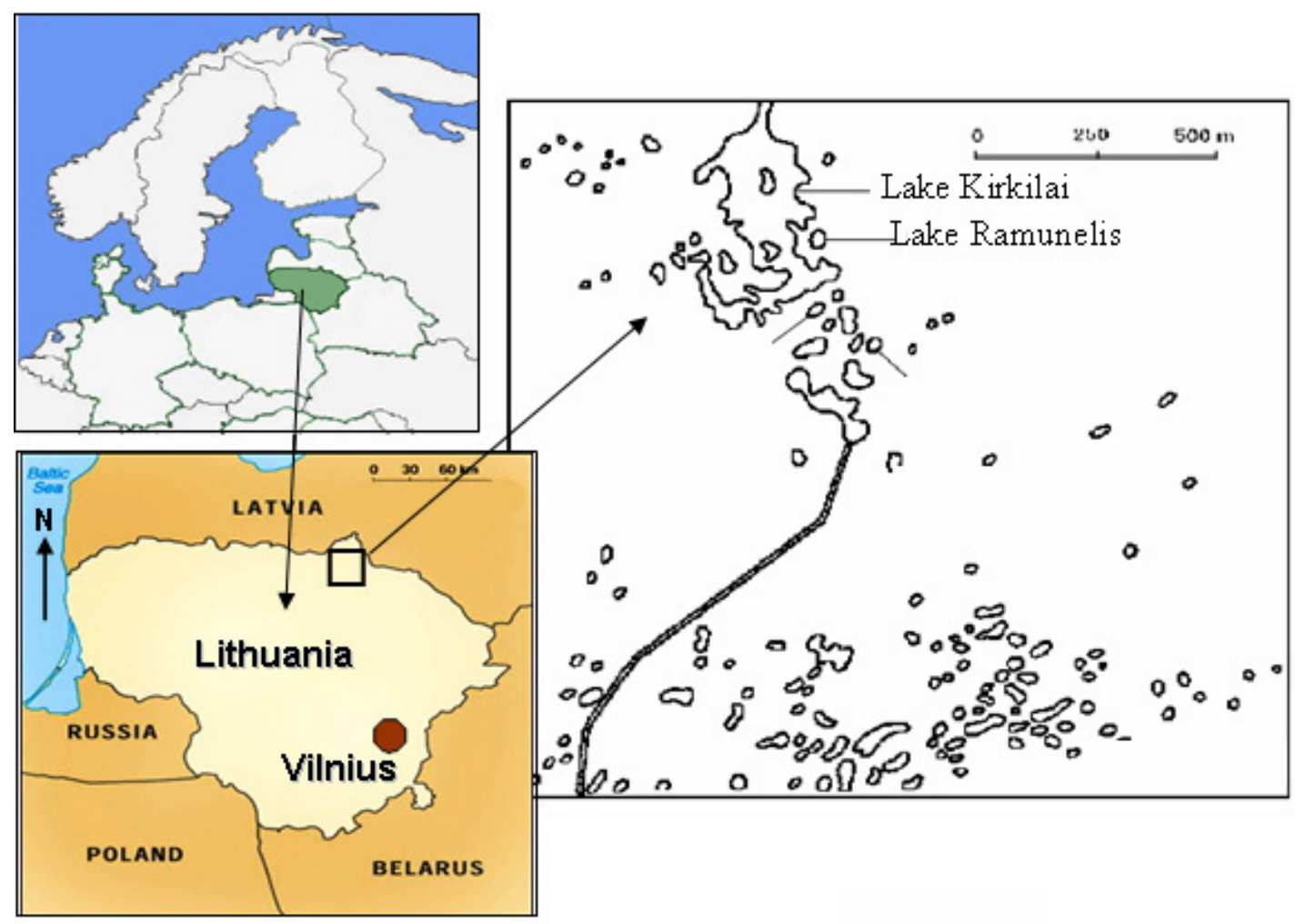

Figure 1

Location of lakes in the gypsum karst region of northern Lithuania.

Figure 1

Localisation des lacs dans la région du karst gypseux du nord de la Lituanie.

\section{> SAMPLING AND ANALYSIS}

The investigations were carried out in the central part of the lakes in August 2008. Water samples were collected with a Ruttner sampler throughout the water column at 1-m intervals. Sediment samples $(0-5 \mathrm{~cm})$ were taken with an Ekman grab. Temperature, $\mathrm{pH}$ and water transparency were measured in situ with a portable universal MultiLine F/Set-3 meter (WTW) and Secchi disk; dissolved oxygen concentrations were determined by Winkler titrations. Dissolved inorganic salt, nutrient, organic matter and sulfate analysis was performed in a certified laboratory (JSC Water Investigations) according to standard methods of water investigation (Merkiene and Ceponyte, 1994). Phosphate-P was assessed via the molybdate ascorbic acid method after digestion with sulfuric acid. The total phosphorus (TP) concentration was measured using the persulfate- $\mathrm{H}_{2} \mathrm{SO}_{4}$ digestion and molybdate ascorbic acid methods. Nitrate-N was determined using potassium persulfate- $\mathrm{K}_{2} \mathrm{~S}_{2} \mathrm{O}_{8}$ following $\mathrm{Cd}$ reduction to $\mathrm{NO}_{2}$. The total nitrogen (TN) was analyzed by the Kjeldahl method, and dissolved organic carbon (DOC) by the dichromate oxidation method. Sulfate concentration was determined by the turbid metric method, which is based on the formation of $\mathrm{BaSO}_{4}$ crystals in a suspension and the subsequent measurement of its optical density spectrophotometrically. Hydrogen sulfide and acid volatile sulfides in sediments were analyzed by the method of Volkov and Zhabina (1980). The fixed sediments were treated with gaseous nitrogen and the total content of collected sulfides was calculated after titration with sodium thiosulfate.

Formaldehyde-preserved (4\% final concentration) phytoplankton samples ( $1 \mathrm{~L}$ ) were concentrated by sedimentation up to $20 \mathrm{~mL}$ (Olrik et al., 1998) and analyzed by light microscopy (Biolar) at 600x. Bacteria were enumerated under epifluorescence microscopy after DAPI staining on black Millipore filters (pore size $0.2 \mu \mathrm{m}$; Kemp et al., 1993). At least 200 bacterial 
cells in 20 fields were counted at $1000 \times$ using an epifluorescence microscope (Olympus IX70). Biebl and Pfenning nutrient media was used to obtain enrichment cultures of purple and green sulfur bacteria (Biebl and Pfenning, 1978). Samples for inoculation were taken from microaerobic and anaerobic water layers. To account for sulfate-reducing bacteria (SRB) from various layers of water and sediment samples, they were inoculated into lactatesupplemented Postgate medium (Postgate, 1984).

Pigment analysis of anoxygenic phototrophic color sulfur bacteria was performed spectrophotometrically using samples obtained from enrichment cultures (UNESCO, 1966; Jeffrey and Humphrey, 1975). Water with enrichments was filtered through $0.45 \mu \mathrm{m} \mathrm{Gf/C}$ filters (Gelman Sciences). Extraction was performed with $90 \%$ acetone for $18-20 \mathrm{~h}$ at $4{ }^{\circ} \mathrm{C}$ in the dark. Then samples were centrifuged at $4000 \mathrm{ratio} / \mathrm{min}$. for $20 \mathrm{~min}$. The wavelength spectrum from 350 to $900 \mathrm{~nm}$ was scanned by spectrophotometer (Helios $\gamma$, Perkin Elmer). The bacteriochlorophyll (Bchl) concentration was calculated according to Takahashi and Ichimura (1970).

The rate of primary production was determined using the ${ }^{14} \mathrm{C}$ method (Kemp et al., 1993). $0.5 \mathrm{~mL} \mathrm{NaH}{ }^{14} \mathrm{CO}_{3}$ (activity $2 \times 10^{5} \mathrm{~Bq} \cdot \mathrm{mL}^{-1}$ ) was added to $100 \mathrm{~mL}$ samples. The samples (three light and two dark bottles) were incubated in situ at various depths for 6 h. Radioactivity was measured by a liquid scintillation counter (Beckman Instruments Inc.).

The intensity of total (aerobic + anaerobic) organic matter mineralization in bottom sediments was determined by the isolated tubes method (Kuznetsov and Dubinina, 1989). Undisturbed sediments were collected using glass cores ( $5 \mathrm{~cm}$ in diameter). Core tubes with and without sediments were carefully filled with near-bottom water. After $24 \mathrm{~h}$ of incubation in situ, the inorganic carbon concentration in the samples was determined by titration with $0.05 \mathrm{~N} \mathrm{HCl}$. Differences in inorganic carbon concentrations between tubes with and without sediments were used to estimate the rate of organic matter mineralization. The sulfate reduction rate (SRR, $\mathrm{mg} \mathrm{S}^{2-} \cdot \mathrm{dm}^{3} \cdot \mathrm{d}^{-1}$ ) was ascertained using the $\mathrm{Na}_{2}^{35} \mathrm{SO}_{4}$ tracer technique (Sorokin, 1999). A $0.1 \mathrm{~mL} \mathrm{Na} 2 \mathrm{SO}_{4}$ solution (Amersham Pharmacia Biotech) of at least $2-3 \times 10^{6} \mathrm{imp} \cdot \mathrm{min}$ radioactivity was added to triplicate $20 \mathrm{~mL}$ glass tubes, which were pushed $0-5 \mathrm{~cm}$ deep into the sediment, so that the sediment layer filled the tube beneath the plunger completely. The tubes were incubated in situ for $24 \mathrm{~h}$. After the chemical treatment of samples, the filters were placed in vials containing $5 \mathrm{~mL}$ of the scintillation cocktail Optiphase Hisafe 3 (Wallac Scintillation Products). Radioactivity was determined using a liquid scintillation counter.

\section{RESULTS}

\section{> ENVIRONMENTAL CONDITIONS}

Physical-chemical parameters revealed vertical patterns characteristic of the summer stratification period (Figure 2). Secchi depth did not exceed $1.0 \mathrm{~m}$ at either site. The temperature in the upper water of Lake Kirkilai reached $21^{\circ} \mathrm{C}$, while near the bottom the temperature was $9.8^{\circ} \mathrm{C}$. In Lake Ramunelis, the banks of which are overgrown with bushes and trees, water temperatures were lower ( 19.7 and $8.3^{\circ} \mathrm{C}$ at the surface and bottom, respectively). The depth of the thermocline was 2-3 m in Lake Ramunelis, and 2-4 $\mathrm{m}$ in Lake Kirkilai. In both lakes, the presence of phototrophic sulfur bacteria at depths of 1.5 to $4 \mathrm{~m}$ was evident from the vivid green water color. The $\mathrm{pH}$ of Lake Kirkilai ranged from 7.78 (at the surface) to 7.27 (near the bottom). In Lake Ramunelis pH ranged from 7.90 to 7.30 at the surface and bottom, respectively. The slight decrease in $\mathrm{pH}$ occurred below a depth of $2 \mathrm{~m}$ in both lakes. Low concentrations of dissolved oxygen were observed in the upper water layer of both lakes (3.20 mg. $\mathrm{L}^{-1}$ and $3.84 \mathrm{mg} \cdot \mathrm{L}^{-1}$ in Ramunelis and Kirkilai, respectively). The absence of oxygen and presence of $\mathrm{H}_{2} \mathrm{~S}\left(0.7-1.0 \mathrm{mg} \cdot \mathrm{L}^{-1}\right.$ in Lake Kirkilai and $1.0-2.7 \mathrm{mg} \cdot \mathrm{L}^{-1}$ in Lake Ramunelis) was observed below a depth of $2 \mathrm{~m}$. With insignificant differences, both lakes' water mineralization, and nutrient and organic matter concentrations were high (Table I). 
(a)

Secchi depth (SD); $\left.\mathrm{T}^{\circ}{ }^{\circ} \mathrm{C}\right) \quad \mathrm{O}_{2}\left(\mathrm{mg} \mathrm{L}^{-1}\right) ; \mathrm{H}_{2} \mathrm{~S}\left(\mathrm{mg} \mathrm{L}^{-1}\right) \quad \mathrm{pH}$

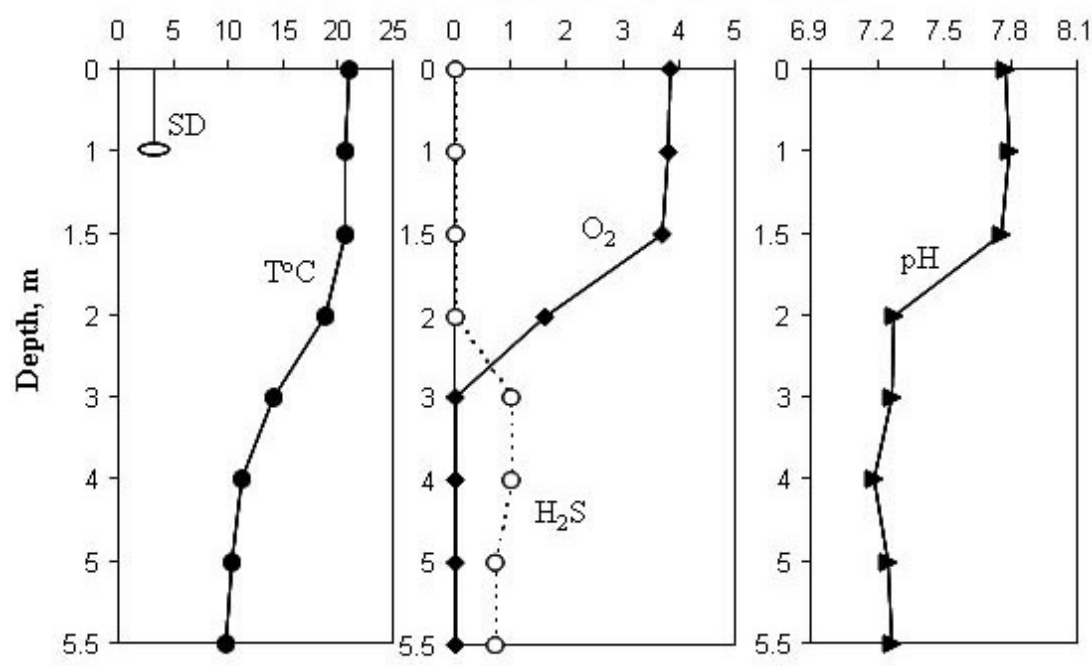

(b)

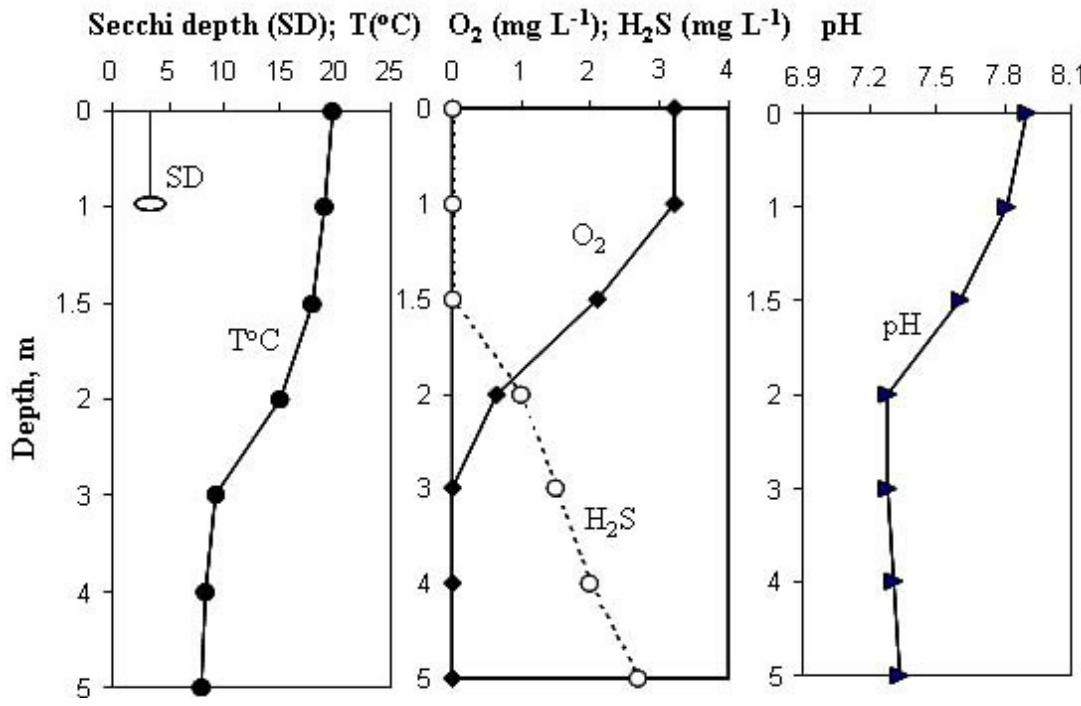

Figure 2

Vertical profiles of physical-chemical parameters in the water column of lakes Kirkilai (a) and Ramunelis (b) during August 2008.

\section{Figure 2}

Profils verticaux des paramètres physico-chimiques de la colonne d'eau des lacs Kirkilai (a) et Ramunelis (b) en août 2008.

\section{$>$ BACTERIA}

In Lake Kirkilai, the highest densities of bacteria were measured in the metalimnion (2 $\mathrm{m})$. In contrast, the highest densities of bacteria in Lake Ramunelis occurred in the hypolimnion (Figure 3). Pigment analysis of green sulfur bacteria cultures showed that maximal light absorption occurred at 436, 654 and $665 \mathrm{~nm}$ (Figure 4). These wavelengths correspond to carotenoids, $\mathrm{Bchl} c$ and Bchl $d$ (respectively) and are characteristic of the green sulfur bacteria genera Chlorobium and Pelodyction (Takahashi and Ichimura, 1970; Pfennig, 1989). Concentrations of bacteriochlorophylls $c$ and $d$ indicate that the most intensive development of green sulfur 


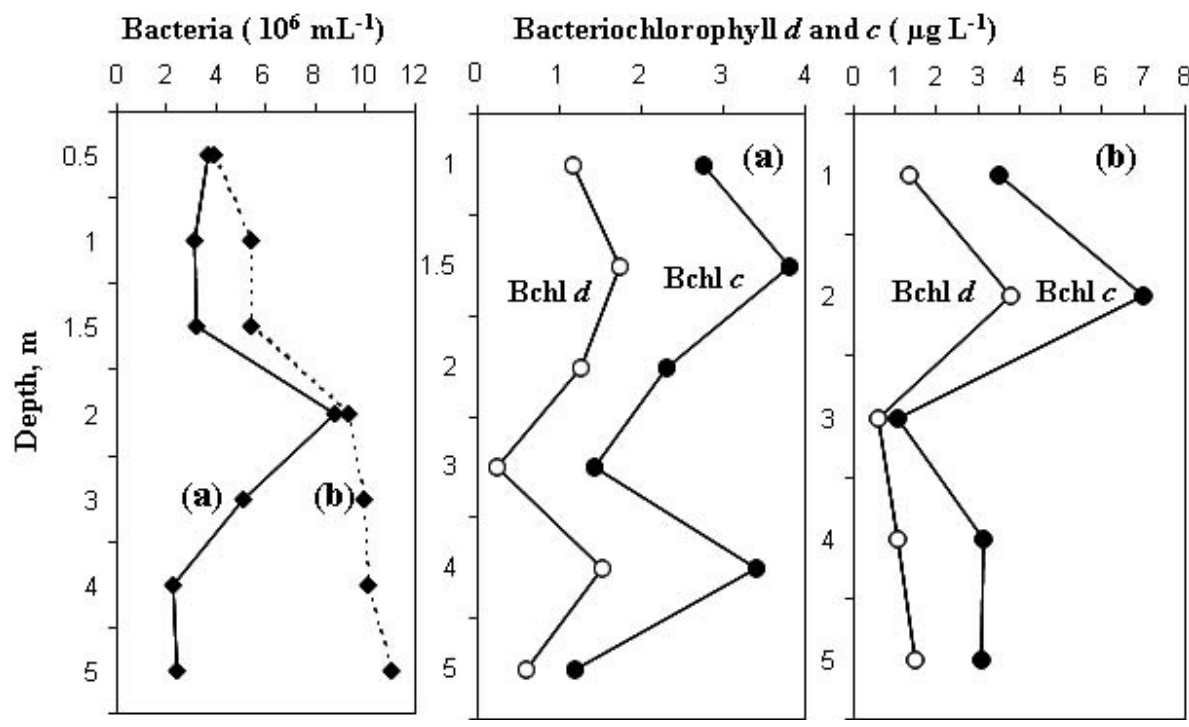

Figure 3

Vertical distribution of bacterial cell densities and concentrations of bacteriochlorophylls (Bchl c and $B c h l d$ ) in enrichment cultures of green sulfur bacteria obtained from lakes Kirkilai (a) and Ramunelis (b), in August 2008.

\section{Figure 3}

Distribution verticale des densités de cellules bactériennes et concentrations de bactériochlorophylle (Bchl $c$ et Bchl $d$ ) dans des cultures enrichies de bactéries photosynthétiques du soufre des lacs Kirkilai (a) et Ramunelis (b) en août 2008.

\section{Table I}

Surface and bottom concentrations of dissolved ions, total nitrogen (TN), total phosphorus (TP), dissolved organic carbon $(D O C)$ and biological oxygen demand $(B O D)$ in two karst lakes in northern Lithuania during August 2008.

\section{Tableau I}

Concentrations en surface et au fond des ions dissous, azote total (TN), phosphore total (TP), carbone organique dissous (DOC) et demande biologique en oxygène (BOD) dans deux lacs karstiques du nord de la Lituanie en août 2008.

\begin{tabular}{|l|c|c|c|c|c|}
\hline Lake & $\begin{array}{c}\Sigma \text { ions, } \\
\mathrm{mg} \cdot \mathrm{L}^{-1}\end{array}$ & $\begin{array}{c}\mathrm{TN}, \\
\mathrm{mg} \cdot \mathrm{L}^{-1}\end{array}$ & $\begin{array}{c}\mathrm{TP}, \\
\mathrm{mg} \cdot \mathrm{L}^{-1}\end{array}$ & $\begin{array}{c}\mathrm{DOC}, \\
\mathrm{mg} \cdot \mathrm{L}^{-1}\end{array}$ & $\begin{array}{c}\mathrm{BOD}_{7}, \\
\mathrm{mg} \mathrm{O}_{2} \cdot \mathrm{L}^{-1}\end{array}$ \\
\hline Kirkilai & ${ }^{*} 500 / 1400$ & $2.0 / 2.3$ & $0.06 / 0.4$ & 24.7 & 7.7 \\
\hline Ramunelis & $600 / 1300$ & $1.6 / 2.08$ & $0.07 / 2.2$ & 21.0 & 5.4 \\
\hline
\end{tabular}

${ }^{*}$ In denominator - in the upper water layer, in numerator - near the bottom.

bacteria occurred in enrichment cultures obtained from microaerobic (Kirkilai) and anaerobic (Ramunelis) water layers (Figure 3). Pigment analysis of purple sulfur bacterial cultures showed that maximal light absorption was also at 436, 654 and $665 \mathrm{~nm}$, with a smaller maxima at $583 \mathrm{~nm}$ that is indicative of Bchl $b$ and characteristic of purple sulfur bacteria. Overall, these data infer that green sulfur bacteria dominated in both lakes.

Sulfate-reducing bacteria were observed below a depth of $2 \mathrm{~m}$ in Lake Ramunelis and $3 \mathrm{~m}$ in Lake Kirkilai (Table II). In the water column, the abundance of these bacteria was similar in both lakes $\left(10^{5} \mathrm{CFU} \cdot \mathrm{mL}^{-1}\right)$, but in the bottom sediments of Lake Kirkilai, abundance was ten-fold higher $\left(10^{6} \mathrm{CFU} \cdot \mathrm{mL}^{-1}\right)$.

The highest morphological bacterial diversity (rods, large oval rods, large spiral forms, vibrios, rods of net structure) was observed in microaerobic and anaerobic layers where hydrogen sulfide was present (Figure 5). Microscopic analysis of bacteria showed that photosynthetic sulfur bacteria developed with sulfate reducers in anaerobic layers. 

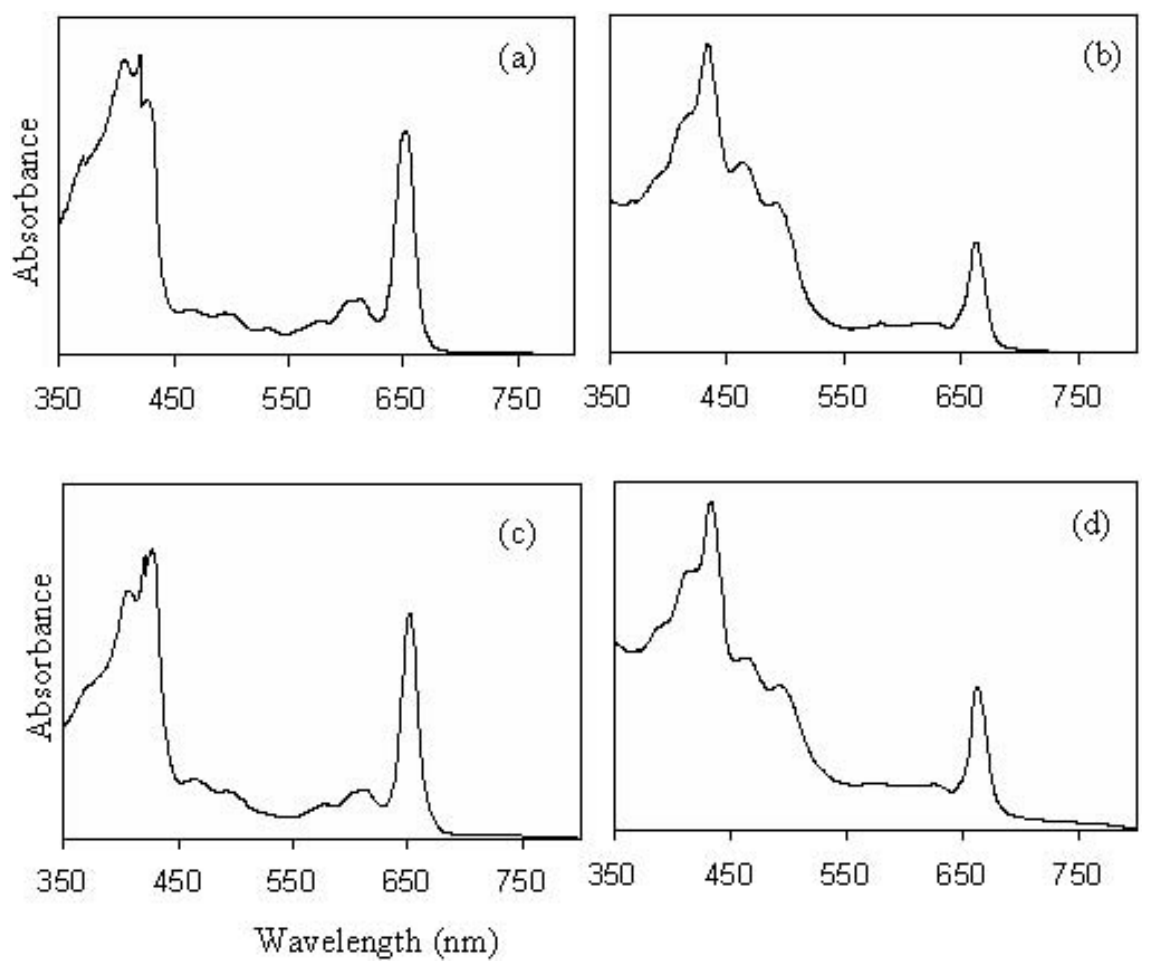

Figure 4

Absorption spectra photosynthetic pigments of green sulfur bacterial enrichment cultures obtained from Lake Kirkilai: (a) from 1.5 m, (b) near the bottom and from Lake Ramunelis: (c) from 2 m, (d) near the bottom.

\section{Figure 4}

Spectre d'absorption des pigments photosynthétiques de cultures enrichies de bactéries photosynthétiques du soufre issues du lac Kirkilai : (a) à 1,5 $\mathrm{m}$ de la surface, (b) près du fond et du lac Ramunelis :

(c) à $2 \mathrm{~m}$ de la surface, (d) près du fond.

\section{Table II}

Vertical distribution of sulfate-reducing bacteria (SRB, CFU $\left.\cdot \mathrm{mL}^{-1}\right)$ in two karst lakes in northern Lithuania during August 2008.

\section{Tableau II}

Distribution verticale des bactéries sulfato-réductrices (SRB, CFU.mL $\mathrm{m}^{-1}$ ) dans deux lacs karstiques du nord de la Lituanie en août 2008.

\begin{tabular}{|l|c|c|}
\hline Depth, $m$ & Lake Kirkilai & Lake Ramunelis \\
\hline $\mathbf{0 . 5}$ & 0 & 0 \\
\hline $\mathbf{1}$ & 0 & 0 \\
\hline $\mathbf{2}$ & 0 & $10^{5}$ \\
\hline $\mathbf{3}$ & $10^{5}$ & $10^{5}$ \\
\hline $\mathbf{4}$ & $10^{5}$ & $10^{5}$ \\
\hline $\mathbf{5}$ & $10^{5}$ & $10^{6}$ \\
\hline Sediments & $10^{6}$ & - \\
\hline
\end{tabular}

“_" Not determined.

\section{> ORGANIC CARBON PRODUCTION RATES}

The highest rates of organic carbon production were measured in the upper water layer $(<1 \mathrm{~m})$ in both lakes (Table III). Green algae (Monoraphidium contortum, Chlorella sp.) dominated in the upper water layer in Lake Kirkilai, while in Lake Ramunelis cyanobacteria (Synechocystis sp.) and golden-brown algae (Ochromonas sp.) were dominant. Carbon 

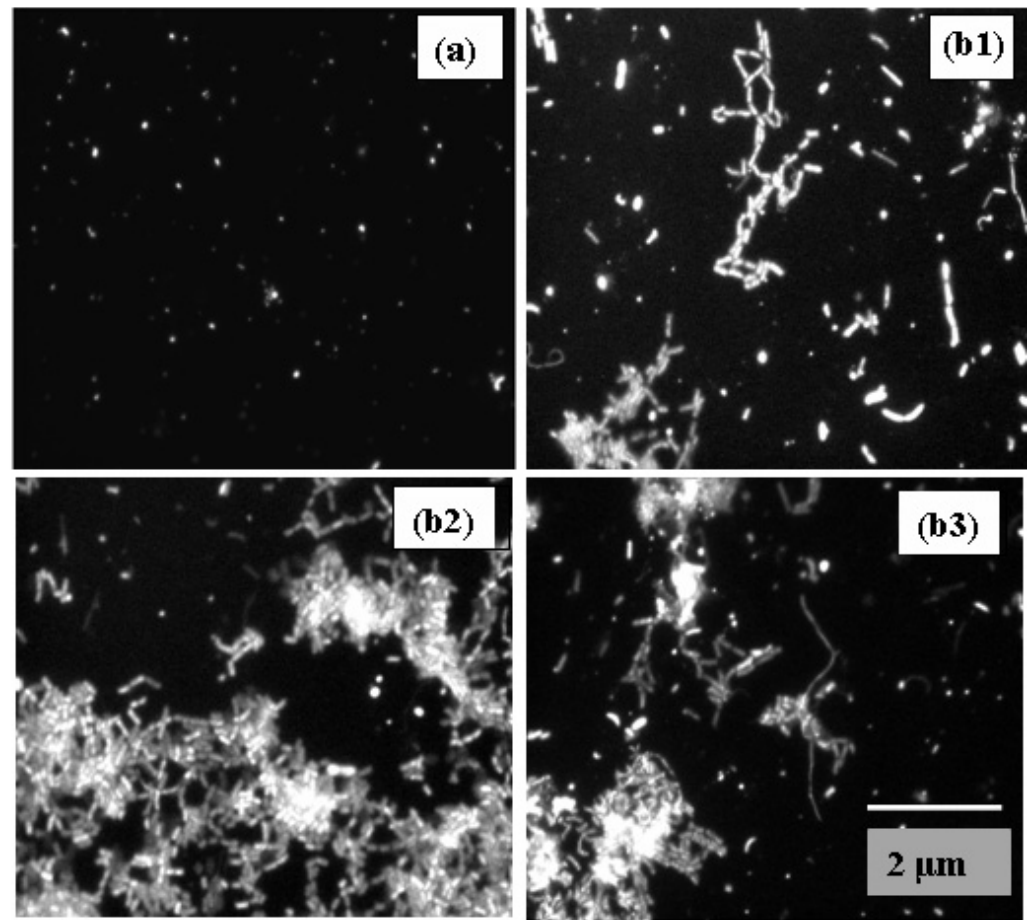

Figure 5

Morphological variety of bacterioplankton in the water of Lake Kirkilai, in August 2008. (a) Bacteria from upper layer; (b1), (b2), (b3) bacteria from 2-3 m depth.

\section{Figure 5}

Diversité morphologique du bactérioplancton dans l'eau du lac Kirkilai, en août 2008. (a) Bactéries de la couche de surface ; (b1), (b2), (b3) bactéries à 2-3 m de profondeur.

\section{Table III}

Photosynthetic organic carbon production rate $\left(m g C \cdot m^{3} \cdot d^{-1}\right)$ in two karst lakes in northern Lithuania during August 2008. Prior data from Zvikas (2004) are included for comparison.

\section{Tableau III}

Taux de production de carbone photosynthétique $\left(\mathrm{mg} \mathrm{C} \cdot \mathrm{m}^{3}\right.$.jour $\left.{ }^{-1}\right)$ dans deux lacs karstiques du nord de la Lituanie en août 2008. Les données antérieures de Zvikas (2004) sont inclues pour comparaison.

\begin{tabular}{|c|c|c|c|c|}
\hline \multirow{4}{*}{ Depth (m) } & \multicolumn{3}{|c|}{ Kirkilai } & \multirow[t]{2}{*}{ Ramunelis } \\
\hline & \multicolumn{3}{|c|}{ Years } & \\
\hline & \multicolumn{2}{|c|}{1998 and 2000-2001 (Zvikas, 2004) } & \multirow[b]{2}{*}{2008} & \multirow[b]{2}{*}{2008} \\
\hline & Min-max & Mean & & \\
\hline 0.5 & $110-2000$ & $800 \pm 800$ & 1212 & 2906 \\
\hline 1 & $68-300$ & $193 \pm 83$ & 348 & 164 \\
\hline 2 & $20-200$ & $116 \pm 64$ & 102 & 104 \\
\hline 3 & $50-100$ & $83 \pm 22$ & 88 & 106 \\
\hline 4 & $20-150$ & $63 \pm 30$ & 67 & 100 \\
\hline 5 & $0-50$ & $27 \pm 18$ & 56 & - \\
\hline
\end{tabular}

“_" Not determined.

production integrated for the metalimnion and hypolimnion accounted for $17 \%$ and $9 \%$ of total carbon photoassimilation in lakes Kirkilai and Ramunelis, respectively. The intensive development of green sulfur bacteria occurred in these sulfide-rich layers. In the anaerobic water layers of both lakes, the presence of cyanobacteria (Synechocystis sp., Oscillatoria tenuis) was also observed. 


\section{Table IV}

Rates of total organic carbon mineralization (TM), sulfate reduction (SRP), concentrations of sulfate $\left(\mathrm{SO}_{4}^{2-}\right)$ and hydrogen sulfide + sulfides $\left(\mathrm{H}_{2} \mathrm{~S}+\mathrm{HS}^{-}\right)$in two karst lakes during August 2008.

\section{Tableau IV}

Taux de minéralisation du carbone organique total (TM), de réduction des sulfates (SRP), concentrations en sulfates $\left(\mathrm{SO}_{4}^{2-}\right)$ et en sulfure d'hydrogène+sulfures $\left(\mathrm{H}_{2} \mathrm{~S}+\mathrm{HS}^{-}\right)$dans deux lacs karstiques du nord de la Lituanie en août 2008.

\begin{tabular}{|c|c|c|c|c|c|c|}
\hline Lake & Depth $(m)$ & $\begin{array}{c}\mathrm{TM} \\
\left(\mathrm{mg} \mathrm{C} \cdot \mathrm{m}^{2} \cdot \mathrm{d}^{-1}\right)\end{array}$ & $\begin{array}{c}\text { SRP } \\
\left(\mathrm{mg} \mathrm{S}^{2-} \cdot \mathrm{dm}^{3} \cdot \mathrm{d}^{-1}\right) \\
\end{array}$ & $\begin{array}{c}\text { Corg. } \\
\text { consumption } \\
\text { for SRP }\left(m g \cdot m^{2} \cdot d^{-1}\right)\end{array}$ & \begin{tabular}{|c|}
$\mathrm{SO}_{4}^{2-}$ \\
$\left(\mathrm{mg} \cdot \mathrm{L}^{-1}\right)$
\end{tabular} & $\begin{array}{c}\mathrm{H}_{2} \mathrm{~S} \\
\left(\mathrm{mg} \cdot \mathrm{L}^{-1}\right)\end{array}$ \\
\hline \multirow{7}{*}{ Kirkilai } & 0.5 & - & 0 & 0 & 327 & 0 \\
\hline & 1 & - & 0 & 0 & - & 0 \\
\hline & 2 & - & 0 & 0 & 690 & 0 \\
\hline & 3 & - & 0.21 & 7.5 & 1173 & 1.0 \\
\hline & 4 & - & 0.23 & 8.0 & 1248 & 1.0 \\
\hline & 5 & - & 0.07 & 3.5 & 1236 & 0.7 \\
\hline & Sediments & $2012-2496$ & 1.97 & 69.5 & 870 & $320\left(\mathrm{H}_{2} \mathrm{~S}+\mathrm{HS}^{-}\right)$ \\
\hline \multirow{6}{*}{ Ramunelis } & 0.5 & - & 0 & 0 & 369 & 0 \\
\hline & 1 & - & 0 & 0 & - & - \\
\hline & 2 & - & 0.03 & 1.0 & 792 & 1.0 \\
\hline & 3 & - & 0.03 & 1.0 & 984 & 1.5 \\
\hline & 4 & - & 0.04 & 1.5 & 657 & 2.0 \\
\hline & 5 & - & 0.02 & 0.5 & 582 & 2.7 \\
\hline
\end{tabular}

“-” Not determined.

\section{> ORGANIC MATTER MINERALIZATION}

Anaerobic conditions and high concentrations of organic carbon in sediments (up to 16\%) resulted in high rates of microbial activity. Up to $2496 \mathrm{mg}$ of inorganic $\mathrm{C} \mathrm{m}^{2} \cdot \mathrm{d}^{-1}$ were released during anaerobic decomposition of organic matter (Table IV). Sulfate reduction was apparent, as sulfate concentrations varied from 369 to $1248 \mathrm{mg} \cdot \mathrm{L}^{-1}$, with the highest concentrations measured in the metalimnion and upper hypolimnion (Table IV). Sulfate reduction was determined in two zones: the bottom sediments of Lake Kirkilai exhibiting the highest rate $\left(1.97 \mathrm{mg} \mathrm{S}^{2-} \cdot \mathrm{dm}^{3} \cdot \mathrm{d}^{-1}\right)$, and the microaerobic and anaerobic layers of both lakes (0.07-0.23 mg and 0.02-0.04 $\mathrm{mg} \mathrm{S}^{2-} \cdot \mathrm{L} \cdot \mathrm{d}^{-1}$ in Kirkilai and Ramunelis, respectively). According to our calculations, from 3.5 to $8.0 \mathrm{mg} \mathrm{C} \cdot \mathrm{m}^{2} \cdot \mathrm{d}^{-1}$ and $69.5 \mathrm{mg} \mathrm{C} \cdot \mathrm{m}^{2} \cdot \mathrm{d}^{-1}$ was mineralized via sulfate reduction in the water and sediments of Lake Kirkilai, respectively. Up to $1.5 \mathrm{mg} \mathrm{C} \cdot \mathrm{m}^{2} \cdot \mathrm{d}^{-1}$ was mineralized in Lake Ramunelis.

\section{DISCUSSION}

Prior studies of the karst lakes Kirkilai and Ramunelis have shown that the most distinct physical-chemical gradients develop during summer stratification (Taminskas, 1997). Low oxygen concentration in upper water layers and its absence below $2 \mathrm{~m}$ depth is characteristic of these lakes during midsummer. The anoxic environment is indicated by the accumulation of reduced products such as $\mathrm{H}_{2} \mathrm{~S}$. The metalimnion with the $\mathrm{O}_{2} / \mathrm{H}_{2} \mathrm{~S}$ intersection zone formed at 2-3 m depth. Elevated mineralization of water, especially near the bottom, greatly depends on the high sulfate concentration resulting from leaching gypsum. Nutrient and dissolved organic carbon concentrations were also high and may reflect the impact of agrarian activities within the basin. Total nitrogen and phosphorus concentrations measured in this study were similar to previously reported values (Taminskas and Marcinkevicius, 2002) and are indicative of eutrophic-hypereutrophic water basins (Brönmark and Hansson, 1998). 
The bacterial densities reported here $\left(2 \times 10^{6}-11 \times 10^{6} \mathrm{cell} \cdot \mathrm{mL}^{-1}\right)$ were higher than those determined in karst lakes in central Povolzhje in Russia $\left(2 \times 10^{6}-6 \times 10^{6} \mathrm{cell} \cdot \mathrm{mL}^{-1}\right)$, where their distribution had few maxima at different depths (Lapteva et al., 1985). In Lake Kirkilai, the highest bacterial densities and greatest morphological diversity occurred in the $\mathrm{O}_{2} / \mathrm{H}_{2} \mathrm{~S}$ intersection zone. The occurrence of high microbial diversity at the oxic-anoxic boundary has also been observed in other karst lakes of sulfate type (Rodrigo et al., 2000). However, in Lake Ramunelis, the highest abundance of bacteria was found in the anaerobic hypolimnion and especially near the bottom. The bottom sediments of this very small lake are covered by a thick layer of fallen leaves. In midsummer during mineralization of these organic substances, negative Eh potential, and high concentrations of biogenic elements and gas were recorded in the anaerobic hypolimnion (Zvikas, 2004), which in turn influences the development and distribution of bacteria.

Light levels and sulfide concentrations are the main factors determining both the vertical distribution and photosynthetic activity of phototrophic bacteria (Vila et al., 1996, 1998). Penetration of light into sulfide-rich anaerobic water layers created favorable conditions for the development of anoxic phototrophic sulfur bacteria in lakes Kirkilai and Ramunelis. Pigment analysis of enrichment cultures showed the intensive development of green sulfur bacteria in anaerobic and especially in microaerobic (1.5-2 $\mathrm{m}$ ) water layers of these lakes. The amount of Bchl $b$ characteristic of purple sulfur bacteria was insignificant. On the contrary, the massive development of purple sulfur bacteria, mainly Chromatium okeanii, was noticed during summer stratification in Lake Kirkilai in 2001 (Zvikas, 2004).

According to Gorlenko (1992), the contribution of phototrophic sulfur bacteria to primary production ranged between 13 and $75 \%$ depending on the trophic state of stratified lakes. In lakes Kirkilai and Ramunelis, photosynthetic production of organic carbon occurs throughout the water column with the highest rates in the upper layer, indicative of eutrophic lakes (Sulijiene, 2000). In anaerobic water layers, green sulfur bacteria developed very intensively and cyanobacteria (Synechocystis sp., Oscillatoria tenuis), which may be facultative anoxygenic (Garlick et al., 1977; Stal and Moezelaar, 1997), were also found. These findings suggest that a portion of organic matter may be synthesized via anoxygenic photosynthesis.

Microscopic analysis revealed that phototrophic sulfur bacteria co-occurred with sulfatereducing bacteria (SRB) in the microaerobic and anaerobic layers. Mutualistic interactions between anoxygenic phototrophic bacteria and sulfate reducers at the oxic-anoxic boundary of meromictic lakes have been previously reported (Overmann and Schubert, 2002). Previous investigations of SRB by molecular methods revealed that among the sulfate reducers Desulfovibrio desulfuricans prevailed in Lake Kirkilai (Paskauskas et al., 2005). SRB were abundant below a depth of $2 \mathrm{~m}$ in Lake Ramunelis and below $3 \mathrm{~m}$ in Lake Kirkilai, where their population density was $10^{5} \mathrm{CFU} \cdot \mathrm{mL}^{-1}$ and increased ten times in sediments. These values are higher than those reported for many other lakes. In the monimolimnion of a meromictic karst lake in Russia (Lake Kuznechiha), the abundance of SRB varied between 10 and $100 \mathrm{CFU} \cdot \mathrm{mL}^{-1}$ and increased up to $10^{5} \mathrm{CFU} \cdot \mathrm{mL}^{-1}$ in reduced bottom sediments (Gorlenko et al., 1980). In sulfate-rich lake Shira, the abundance of SRB was $2 \times 10^{2} \mathrm{CFU} \cdot \mathrm{mL}^{-1}$ in water and $2 \times 10^{5} \mathrm{CFU} \cdot \mathrm{mL}^{-1}$ in sediments (Kosolapov et al., 2003). In non-karst lakes in Lithuania, the abundance of SRB ranged from 10 to $10^{3}$ cells $\cdot \mathrm{mL}^{-1}$ (Kucinskiene and Paskauskas, 2003).

In the water column of lakes Kirkilai and Ramunelis, sulfate reduction was observed from the $\mathrm{O}_{2} / \mathrm{H}_{2} \mathrm{~S}$ intersection zone, with the highest rates just below it. The vertical profile of the sulfate reduction rate in lakes Kirkilai and Ramunelis was similar to those of miromictic lakes (Kosolapov et al., 2003). The high concentration of sulfate and quantitative/qualitative structure of organic matter are factors influencing the functional activity of SRB (Cook, 1992; Holmer and Storkholm, 2001). In spite of the high concentration of sulfate in karst lakes, the rate of sulfate reduction in bottom sediments was similar to shallow lakes influenced by organic pollution (Krevs and Kucinskiene, 2009). The accumulation of higher-molecularweight organic compounds in karst lakes, overgrown with bushes and trees, determines the character of sulfate reduction. The mineralization of organic matter into acceptable substrate occurs more slowly, and competition for easily assimilated organic carbon between 
sulfate-reducing and other anaerobic bacteria takes place as well. However, sulfate reduction reached $11.36 \mathrm{mg} \mathrm{S}^{2-} \cdot \mathrm{dm}^{3} \cdot \mathrm{d}^{-1}$ in bottom sediments enriched with detritus of planktonic origin in local areas (Paskauskas et al., 2005). It suggests that karst lakes are very sensitive to organic pollution and especially to organic fertilizer because under such impact, and in the presence of high sulfate amounts, sulfate reduction may become very intensive and, consequently, the release of hydrogen sulfide and development of sulfur cycle bacteria may reduce the variety of other hydrobionts as well.

Ecological conditions specific to karst lakes including the presence of an anaerobic hypolimnion with $\mathrm{H}_{2} \mathrm{~S}$, high amounts of $\mathrm{SO}_{4}^{2-}$, nutrients and organic matter, and extension of the photic zone up to anaerobic water layers influence the vertical distribution and abundance of bacteria in lakes Kirkilai and Ramunelis. Some of these characteristics differed insignificantly in the two neighboring lakes. Based on nutrient and organic matter concentrations, and the midsummer photosynthetic organic carbon production rate in the aerobic zone, Kirkilai and Ramunelis may be described as eutrophic lakes.

\section{ACKNOWLEDGEMENTS}

We are very grateful to Dr. J. Karosiene for the identification of dominating phytoplankton species and to V. Ptasekiene for the revision of the English language of this manuscript. This study was supported by the Lithuanian State Science and Studies Foundation (project No. T-88/08).

\section{REFERENCES}

Alimova A.F. and Mingazova N.M. (eds.), 2001. The unique ecosystems of karst lakes in the middle Povalzhie, Kazan, 256 p. (in Russian).

Biebl H. and Pfennig N.P., 1978. Growth yields of green sulfur barteria in mixed culture with sulfur and sulfate reducing bacteria. Arch. Microbiol., 117, 9-16.

Brönmark Ch. and Hansson L.-A., 1998. The biology of lakes and ponds, Univers. Press, Oxford, 216 p.

Camacho A., Vicente E. and Miracle M.R., 2000. Spatio-temporal distribution and growth dynamics of phototrophic sulfur bacteria populations in the sulfide-rich Lake Arcas. Aquat. Sci., 62, 334-349.

Camacho A., Picazo A., Miracle M.R. and Vicente E., 2003. Spatial distribution and temporal dynamics of picocyanobacteria in a meromictic karstic lake. Algol. Stud., 109, 171-184.

Cook R., 1992. Controls of sulfur cycling in small lakes. Interact. Biogeochem. Cycl. Aquat. Ecosyst., 7, 211-223.

Garcia-Gil L.J., Casamitjana X. and Abella C.A., 1996. Comparative study of two meromictic basins of Lake Banyoles (Spain) with sulphur phototrophic bacteria. Hydrobiologia, 319, 203-211.

Garlick S., Oren A. and Padan E., 1977. Occurence of facultative anoxygenic photosynthesis among filamentous and unicellular cyanobacteria. J. Bacteriol., 129, 623-629.

Gorlenko V.M., 1992. The role of purple and green bacteria in the carbon and sulphur cycles in stratified lakes. In: Degens E.T., Kempe S., Lein A. and Sorokin Y. (eds.), The Interactions of Biogeochemical Cycles in Aqueous Systems, 7, Hamburg, 51-57.

Gorlenko V., Dubinina G. and Kuznecov S., 1977. Ecology of the water microorganisms, Nauka, Moscow, 287 p. (in Russian).

Gorlenko V., Vajnshtein M. and Chebotor'ov E., 1980. Bacteria of sulfur and iron cycling in the meromictic Lake Kuznechiha. Microbiology, 59, 804-812.

Gusev E., 2008. Phytosynthetic pigments of plankton in some karst lakes of central Russia. Inland Wat. Biol., 1, 217-224.

Holmer M. and Storkholm P., 2001. Sulphate reduction and sulphur cycling in freshwater sediments: A review. Freshwater Biol., 46, 431-451.

Jeffrey S.W. and Humphrey G.F., 1975. New spectrophotometric equation for determining chlorophyll a, $b, c_{1}$ and $c_{2}$. Biochem. Physiol. Pfl., 167, 191-194.

Kemp P.F., Sherr B.F., Sherr E.B. and Cole J.J. (eds.), 1993. Handbook of Methods in Aquatic Microbial Ecology, Lewis Publishers, 800 p.

Kilkus K. and Taminskas J., 2000. Geographical conditions of nature use in the Karst region. In: Griniute D. and Matukoniene V. (eds.), The Northern Lithuanian Karst Region, Institute of Geography, Vilnius, 67-78. 
Kosolapov D., Rogozin D., Gladchenko I., Kopylov A. and Zakharova E., 2003. Microbial sulfate reduction in a brackish meromictic steppe lake. Aquat. Ecol., 37, 215-226.

Krevs A. and Kucinskiene A., 2009. Microbial mineralization of organic matter in bottom sediments of small anthropogenised lakes. Ekol., 55, 125-130.

Kucinskiene A. and Paskauskas R., 2003. Bacterial sulphate reduction in Lithuanian lakes. Geogr. Yearbook, 36, 53-67.

Kuznetsov S. and Dubinina G., 1989. Methods of investigation of aquatic microorganisms, Nauka, Moskow, 285 p. (in Russian).

Lapteva N., Dubinina G. and Kuznecov C., 1985. Microbiological characteristics of some karstic lakes in Gorkij region. Hydrobiol. J., 21, 61-68.

Miracle M., Vicente E. and Pedrós-Alió C., 1992. Biological studies of Spanish meromictic and stratified karstic lakes. Limnetica, 8, 59-77.

Merkiene R. and Ceponyte V., 1994. Unified sewage and sutface waters quality assessment methods, 1, Vilnius, 221 p. (in Lithuanian).

Olrik K., Blomqvist P., Brettum P., Cronberg G. and Eloranta P., 1998. Methods for Quantitative Assessment of Phytoplankton in Freshwaters, Naturvårdsverket Stockholm, $86 \mathrm{p}$.

Overmann J. and Garcia-Pichel F., 2006. The phototrophic way of life. In: Dworkin M., Falkow S., Rosenberg E., Schleifer K.-H. and Stackebrandt E. (eds.), The Prokaryotes, Springer, 2, New York, $32-86$.

Overmann J. and Schubert K., 2002. Phototrophic consortia: model systems for symbiotic interrelations between prokaryotes. Arch. Microb., 177, 201-208.

Palagushkina O., 2004. Ecology of phytoplankton in karst lakes of middle Povolzhie. Summary of doctoral dissertation, Kazan, 25 p. (in Russian).

Paskauskas R., Kucinskiene A. and Zvikas A., 2005. Sulfate-reducing bacteria in gypsum karst lakes of northern Lithuania. Microbiology, 74, 715-721.

Pfennig N., 1989. Ecology of phototrophic purple and green sulfur bacteria. In: Schlegel H.G. and Bowien B. (eds.), Autotrophic Bacteria, Berlin, Heidelberg, New York, Springer, 97-116.

Postgate J.R., 1984. The Sulfate-Reducing Bacteria, Second edition, Cambridge Univer. Press, 208 p.

Rasomavicius V. (ed.), 2001. Habitation of European significance in Lithuania. Explanatory guide of significant habitations for Europe Union detected in Lithuania, Vilnius, 138 p. (in Lithuanian).

Rodrigo M.A., Vicente E. and Miracle M.R., 2000. The physical, chemical and biological characteristics of the holomictic sulphated Lake Arcas-2 (Cuenca, Spain). Hydrobiologia, 418, 153-168.

Sorokin Ju., 1999. Aquatic Microbial Ecology, Backhaus publishers, $247 \mathrm{p}$.

Stal L. and Moezelaar R., 1997. Fermentation in cyanobacteria. FEMS Microb. Rew., 21, 179-211.

Sulijiene R., 2000. Primary production of phytoplankton in the freshwater ecosystems of Lithuania. Acta Hydrobiol. Lithuan., 11, 32-40.

Takahashi M. and Ichimura S., 1970. Photosynthetic properties and growth of photosynthetic sulphur bacteria in lakes. Limnol. Oceanogr., 15, 929-944.

Taminskas J., 1997. Hydrological peculiarities of watershed karst. Geogr. Yearbook, 36, 53-67.

Taminskas J. and Marcinkevicius V., 2002. Karst geoindicators of environmental change: the case of Lithuania. Env. Geol., 42, 757-766.

UNESCO, 1966. Determinations of photosynthetic pigments in seawater - Monographs and Oceanographs, Methodology, Paris, $1 \mathrm{p}$.

Vicente E. and Miracle M.R., 1988. Physicochemical and microbial stratification in a meromictic karstic lake of Spain. Vert. Int. Ver. Limnol., 23, 522-529.

Vila X., Dokulil M., Garcia-Gil L.J., Abella C., Borrego C.M. and Bañeras L., 1996. Composition and distribution of phototrophic bacterioplankton in the deep communities of several central European lakes: The role of light quality. Arch. Hydrobiol. Spec. Issues Adv. Limnol., 48, 183-196.

Vila X., Abella C., Figueras J. and Hurley J., 1998. Vertical models of phototrophic bacterial distribution in the metalimnetic microbial communities of several freshwater North-American kettle lakes. FEMS Microbiol. Ecol., 25, 287-299.

Volkov I. and Zhabina N., 1980. Methods of determination of various sulfur compounds in marine sediments, Nauka, Moskow, 216 p. (in Russian).

Zvikas A., 2004. Structure of microorganisms and peculiarities of their activity in gypsum kars lakes of North Lithuania. Summary of doct. dissertation, $35 \mathrm{p}$. 